\title{
Marketing and Operational Aspects of the Strategy of Industrial Import Substitution
}

Submitted 05/01/19, 1st revision 28/02/19, 2nd rervision 14/05/19, accepted 07/06/19

$$
\text { V.A. Bespalko }{ }^{1} \text {, A.A. Voronov }{ }^{2} \text {, O.V. Martynenko }{ }^{3}
$$

\begin{abstract}
:
Purpose: The purpose of the article is to present the development and implementation of effective marketing strategies related to industrial import substitution.

Design/Methodology/Approach: The article reveals the features and prospects of marketing and operational strategies that accompany the activities of Russian enterprises in the domestic market. Prospects of mobilization of reserves of industrial import substitution, their marketing and financial value in the context of growth of competitive stability and competitiveness are characterized.

Findings: The results consists in the development of tools for strategic marketing management of industrial markets based on the feasibility and necessity of using the indicator of competitive stability among the strategic priorities of the functioning and sustainable development of industrial enterprises.

Practical implications: The applied value of the study is expressed in the disclosure of the content, features and effectiveness of marketing and competitive strategies, justified by the possibility of using the authors' marketing forecast in the long-term business plans, marketing and competitive strategies.

Originality/value: The originality of this approach is to acknowledge assumptions about the need to increase the marketing agility of the subjects of industrial marketing due to the substantial reorientation of functional marketing strategies on the achievement and retention of competitive sustainability.
\end{abstract}

Keywords: Competitive strategy, marketing in industry and agriculture, competitive stability.

JEL Codes: D10, D11, D30, D39.

Paper Type: Research article in Special Issue dedicated to Russian Economy.

Section 8: Business and Economic Issues.

\footnotetext{
${ }^{1}$ Ph.D. in Economics, Associate Professor, Professor of the Department of Management and Trade of Krasnodar Cooperative Institute (branch of the Central Union of Russian Federation «Russian University of Cooperation», bespalko@mail.ru

${ }^{2}$ Dr. Sc. in Economics, Professor of the Department of Marketing and Trade of Kuban State University, voronov.a@mail.ru

${ }^{3}$ Ph.D. in Economics, Associate Professor of the Department of Finance and Credit of Kaliningrad State Technical University, oksana.martynenko@klgtu.ru
} 


\section{Introduction}

The relevance of the research topic is determined by the need to find and implement effective marketing strategies aimed at sustainable functioning and development of corporate structures in the conditions of volatility of competitive marketing environment and the possibility of forming the basis of competitive stability by managing the level of loyalty of target client groups.

\section{The Strategic Management of Price and Non-price Competition}

From the point of view of strategy of marketing management of the modern industrial enterprise free competition is characterized by a number of negative effects significantly reducing efficiency of strategic and tactical marketing influences: chaotic and fragmentary formation of economic space regarding the market and competitive environment of the industrial markets, impossibility of effective administration of processes of the competition from the regulator and their sliding in a zone of predatory / unfair competition, lack of stability and sustainability of functioning and development of both systems of industrial products and service markets and their basic subjects, for example national producers of the most important types of industrial products (Bondarenko et al., 2017; Marwa et al., 2017).

Among the positive marketing effects of a free (unregulated) form of organization of industrial markets are the lack of frameworks and requirements for the composition and structure of methods and means of marketing management and interaction, high requirements for the continuous mobilization of all types of corporate resources, the need for their effective recombination and concentration on promising marketing opportunities, the possibility on this basis of accelerated development of competitive and selection of non-competitive subjects of industrial market.

At the same time, functioning of the basic markets of industrial products can not occur in a spontaneous format of marketing interaction due to the risk of reducing the productivity of competitive processes due to predatory, unfair and anticompetitive actions, the possibility of loss of production capacity for the production of important types of industrial products, the formation of critical import dependence and related threats to national security in terms of production and consumption of industrial products. Most industrial markets are quite amenable to the introduction of a specialized system of marketing restrictions and functioning in the format of limited (effective competition), implying the elimination of the prerequisites for monopolization of marketing processes, the settlement of predatory and unfair competitive initiatives, overcoming competitive asymmetries and deformations, effective competitive administration and development.

The direct consequence of limiting the spontaneity of the competitive type of marketing interaction within industrial markets should be the increase in the productivity of competitive processes associated with the long-term positive 
dynamics of industrial enterprises, industries, complexes on the basis of a systematic increase in the competitiveness of domestic production and growth of its consumption within regional, national and global markets. The development of productive competition requires the use by the regulator of a set of specialized measures for the formation and optimization of systems of industry and marketing barriers, strategic interaction in the monitoring and administration of competition processes, the development and implementation of specific strategic programs for the growth of industry competitiveness and the promotion of competitive type of consumer behavior.

Competitive stability can be considered as a quantitative reference point of industrial marketing strategy, which allows to assess the possibility of reducing sales in the competitive sector in terms of their impact on the operational and marketing results of an economic entity. The authors' methodological innovations in terms of formulas for calculating the absolute and relative competitive stability allow to formalize the existing relations that characterize the structure of the corporate sales portfolio of an industrial enterprise by the criterion of rationality of the type of consumer behavior and move to the calculation of the indicator of the reserve of competitive stability. Supply competitive stability characterizes the decrease in sales in competitive markets are possible without compromising critical reproductive processes and reflecting a tactical scale volatility marketing-competitive market.

The specific results of attracting competitive stability among the priorities of the marketing strategy of a modern industrial enterprise should be: the presence of a flow of loyal transactions, ensuring break-even in the conditions of volatility of the marketing environment of the support markets, reducing sensitivity to the situational marketing impacts of competitors, increasing the efficiency of marketing costs to retain key customers and increase their loyalty, implementation of the principles of sustainable operation and development of the industrial enterprise, creation of prerequisites for active marketing, including competitive activity in highly marginal industrial markets.

The analysis of the content of the main marketing approaches to the organization of management and marketing adaptation of industrial enterprises to the volatility of the competitive environment of industrial markets led to the conclusion that the «competitive demagogy» in the form of unjustified Declaration of the imaginary advantages of free (or rather - natural) competition should in the long term free the marketing space of industrial markets from predatory and unfair marketing strategies of the short term, and producers should focus on a productive competitive format, participation in competition with a foothold of competitive stability and effective functioning on the basis of maneuver and initiatives of marketing and industry specifics. The innovations proposed by the authors (the model of strategic industrial marketing «Profitability of marketing strategy / Intensity of competitive processes», variants of marketing and competitive strategy of an industrial enterprise taking into account the possibilities of winning a competitive initiative and/or implementation 
of a competitive maneuver, the system of principles of industrial marketing adapted to the specifics of marketing strategies based on the priority of competitive stability) are designed to provide effective applied implementation of reserves and marketing chances, embedded in the architecture of industrial markets with a differentiated intensity of competitive processes, can significantly help existing and prospective manufacturers in the development and evaluation of the effectiveness of strategic, operational and tactical impacts of competitive specifics.

Modern methods of development of marketing and competitive strategies in industry includes 4 basic directions: development of competitive potential of producers; strategic and operational formats of competitive marketing impacts; development of competitive environment of industrial markets; a set of competitive strategies that use as the core criterion of competitive stability.

The system tools of formation and commercialization of competitive potential as the basis of industrial competitiveness is currently in the stage of theoretical search, and its use in the marketing strategies of competition of price and non-price type is not formalized and remains in the rank of authors' innovations. It is necessary to recognize insufficiently proved connection between scales and methods of formation of competitive or resource potential and final estimates of competitiveness of production and producers in the industrial markets.

We note a significant methodological gap in the existing strategic and operational approaches to the implementation of marketing management of industrial enterprises in a volatile competitive environment: they are descriptive and do not allow to identify significant determinants of volatility of industrial markets (although the structure and models of consumer behavior of the basic client groups represented within a particular market are quite amenable to research using the basic and innovative marketing research methodology). We also emphasize the existing shortage of scientific ideas in terms of ensuring the effective integration of the functional and systemic nature of the marketing and operational strategy of industrial enterprises (traditionally, these functions are separated and provided by linearly interacting units in the structure of the industrial enterprise), although the implementation of an effective competitive strategy requires a systematic decentralization of the function of industrial marketing and its mass implementation at all stages of the implementation of the multi-format model of industrial business.

The analysis of the methods and tools of competitive administration of industrial markets presented in the study points to the rudimentary level of these management levers, which is extremely insufficient to solve a specific significant economic problem - the effective satisfaction of the needs of the population of the Russian Federation in high-quality and affordable industrial goods of a wide range, the production of which is economically profitable and sustainable, and import dependence is characterized by an initial level that does not have critical values. The Federal Antimonopoly service of Russia (FAS) does not distinguish between free 
and differentiated conditions of competition in industrial markets, in fact, formally interpreting in a convenient form the theory of competition and transforming it into all growing managerial powers, not related to the final economic result.

According to our deep conviction, the «competitive demagogy» existing today in the form of unjustified Declaration of imaginary advantages of free (or rather spontaneous) competition should in the long term free the marketing space of industrial markets from predatory and unfair marketing strategies of the short term, and manufacturers should focus on a productive competitive format, participation in competition with a foothold of competitive stability and effective functioning on the basis of maneuver and initiatives of marketing and industry specifics. One of the necessary directions of development of marketing methods of strategic management of industrial enterprises on the basis of competitiveness of products is the simulation tools, covering two key areas:

- formalized models of product competitiveness, basic on the calculation and interpretation of univariate and multifactor integrated indicators;

- simulation models of competitiveness of producers, describing algorithms and scenarios for the implementation of marketing and competitive strategies within markets with dynamic competitive environment.

The authors' approach to calculation of marketing competitiveness of industrial products based on the methods of the net present value of acquisition and operation has been tested in relation to the specifics of the use of one of the most important types of industrial products - freight rail cars of the most common models. The number of constraints accompanying applied using the authors' model of competitiveness, should include leveling factors accompanying the operation and is able to some extent to adjust the final evaluation of the competitiveness (terms of delivery, a discount from the price, the availability and cost of technical maintenance and planned repairs, the possibility of their own forces, etc).

Nevertheless, the proposed model provides the possibility of correct calculation of economically justified competitiveness index based on the marketing features of a particular type of production and technical purpose, as well as its use in forecasting the competitiveness of current and future models of freight cars. The perspective direction in methodology of development, realization and an assessment of efficiency of the competitive strategies of the industrial marketing considering the factor of volatility of the marketing conjuncture of the markets of production and technical appointment is the imitation modeling urged to provide calculation and valid interpretation of estimates of corporate competitiveness as result of strategic marketing management.

For modernization of existing modeling tools competitive distribution markets products for industrial purposes we have proposed and tested a simulation of competitive marketing model of distribution to a variety of markets the most 
important product PTP (production and technical purpose) - rail freight cars. The aim of the simulation was to create a valid and representative quantitative model, a justified system of equations that allows to convert the initial data on the marketing environment of the element of the set of target markets (production/supply and demand) into the final operational results (sales and balances), taking into account the adjustment of the effectiveness of the marketing and competitive strategy of the manufacturer on the factor of the presence and activity of the competitive environment.

The authors' development made it possible to overcome the existing early limitations in terms of the use of simulation models of competitive distribution of the market of PTP (production and technical purpose) products in relation to the specifics of many isolated local / regional markets. This model provides a representative and valid calculation of the distribution of isolated markets with differentiated marketing and competitive environment. The validity of the calculated results is confirmed by the use of fundamental factors of competitiveness and competitive stability of marketing entities, such as the cost of fixed costs, cost effectiveness for the implementation of marketing information functions, the feasibility and importance of competitive maneuver in the presence of a reserve of unsold products within individual local markets. The implemented steps of calculation characterize the need for timely marketing adaptation of the subjects of many markets to the dynamics of not only the General market situation, but also to changes in supply and demand within the target segments, more or less isolated from the general marketing space.

As perspective directions of improvement of authors' model development it is necessary to note possibility and expediency of its calculation on actual data of various types of freight railway cars (the main cars, tanks, dump cars, hoppers, gondola cars, platforms, other types of freight not self-propelled railway cars), and also complication of level and scales of calculation of model according to data on structure of consumer demand, differentiated by the level of loyalty / rationality of consumer choice within each segment of the set of target markets of the considered products for industrial purposes.

The study allowed to obtain the following results. We have quantitatively characterized the parameters of competitiveness and level of exports within the domestic market of engineering products that require solutions to the economic problem of reducing import dependence through effective import substitution in the domestic markets of high-tech industrial engineering products, the solution of which will stabilize the financial flows of the state scale, will give a new impetus to the development of the most progressive and innovative sector of industry, with global competitiveness potential of (BRF, 2018).

The contribution to effective import substitution should be made on the basis of qualitative growth of efficiency and importance of marketing and competitive 
strategies based on the implementation of the principle of competitive stability and aimed at creating long-term centers and poles of industrial development with strategic potential for competitiveness growth (Consultant, 2018). Production of freight railway cars is one of the most important types of industrial activity in the Russian transport engineering due to the scale of activity of the main buyers of products - owners of rolling stock, providing the entire sector of freight rail transport.

For the period 2013-2016, the volume of the domestic market for the considered type of products decreased more than twice: from 99 to 40.6 billion rubles $(58.4$ billion rubles or 59\%), followed by a sharp progressive dynamics (in the 3 quarters of 2017 - more than twice compared to the same period in 2016 and 1.91 times more than the entire production in 2016) (FSSS, 2018).

The decline of supply on the market in its lower point (2015) is made up 20199 units with the fall from the 2013 level by $73 \%$, from the level of 2014 of $37.4 \%$. Despite the increase in the volume of supply to 31263 units of cars in 2016, the market has not yet recovered from the recession, the consequences of which the industry will feel at least until 2020 (GPIS, 2014). It should be noted that this type of product is characterized by an extremely low level of import dependence in the overall supply structure, associated primarily with one of the natural marketing barriers.

\section{Prospects for the Implementation of Marketing and Operating Strategies}

To understand the prospects of marketing and competitive activity of the largest national manufacturers of the most important type of industrial products - we made an attempt of marketing forecasting of a conjuncture of production, the offer and sale taking into account factors of export and import, and also balances of production and consumption, and also demand and offer on the basis of quantitative estimates of Alto Consulting Group (the largest specialized research Russian organization specializing in monitoring of dynamics of the internal market of a rolling stock).

In accordance with the presented forecasts to 2021, the growth in domestic production of freight rolling stock - railway cars should be 99-100 thousand units in the presence of 6-7 thousand units of imports, and 9-10 thousand units of export sales. Taking into account these amendments, the total supply can be 97-98 thousand units, and the volume of demand should generally correspond to these values. The market in question is one of the balanced marketing systems, the minimum supply surplus during the forecast period, in fact, acts as a rhinestone reserve in case of unpredictable purchases.

\section{Conclusion}


The predicted positive marketing environment can and should become the basis for the applied implementation of marketing and competitive strategies aimed at creating a basis for competitive stability through a number of promising innovations of organizational and technical nature.

\section{References:}

Artamonova, O.V. 2017. The relevance of using digital-tools in promoting the product on the current market. Young scholar, 10, 184-187.

Bondarenko, A.V., Parkhomenko, V.T., Erokhina, B.T., Guzenko, V.N. 2017. Marketing and Logistic Instrumentarium of Activation of Inter-Country Cooperation of Russia and Solving the Issue of Import Substitution. European Research Studies Journal, 20(1), 105-116.

BRF. 2018. The Budget of Russia in Figures. http://investorschool.ru/byudzhet-rossii-2018v-cifrax.

Consultant. 2018. Available at:

http://www.consultant.ru/document/cons_doc_LAW_144190/86100fe66c1448fb6270 $1 \mathrm{~d} 35 \mathrm{f} 1643 \mathrm{~d} 2886937 \mathrm{bea} /$

Florida, R. 2007. Creative class: people who change the future. Classics-XXI, 10.

FSSS. 2018. Federal State Statistics Service. Entrepreneurship, http://www.gks.ru/wps/wcm/connect/rosstat_main/rosstat/ru/statistics/enterprise/.

Ganus, S.M. 2009. Marketing as a tool to ensure the economic security of market activities. Economics and Management, 2, 132-137.

Golubkov, Ye.P. 2000. Marketing as a concept of marketing management. Marketing in Russia and overseas, 2, 95.

GPIS. 2014. Government Program on Import Substitution. https://zimport.ru/programmapravitelstva-po-importozameshheniyu-do-2020-goda.

Magomedov, A.A. 2012. Reproduction Mechanism for the Economic Security of a Region. Business in Law, 1, 326-331.

Malykhina, M.A. 2015. The evolution of marketing communications to integration with quality management. Education. Science. Scientific personnel, 2, 276-282.

Martyshenko, Ye.I. 2011. Marketing concept in the process of strategic management of a Russian enterprise. Theory and Practice of Social Development, 3, 356-358.

Marwa, T., Bashir, A., Azwardi, M.A., Thamrin, H.M.K. 2017. Market Integration of Agricultural Products. International Journal of Economics \& Business Administration, 5(2), 69-82. 